\title{
PENGARUH DANA PERIMBANGAN DAN PENDAPATAN ASLI DAERAH (PAD) TERHADAP PERTUMBUHAN EKONOMI MELALUI BELANJA MODAL DI KOTA DALAM WILAYAH JAWA TIMUR (TAHUN 2009-2014)
}

\author{
Fani Wiraswasta, M. Pudjihardjo, Putu Mahardika Adis \\ Universitas Brawijaya \\ Email: funki.bener@gmail.com
}

\begin{abstract}
This research aims to examine and anylize the effects of balance fund and local revenue to the economics growth trhough capital expenditure in the city of east java from 2009 to 2014. The samples was determined by purposive sampling or judgement sampling technique in which taking from financial statement data of eight cities in east java particularly in local revenue, capital expenditure, and economics growth report in the period 2009-2014. The secondary data was collected from budget revenue and expenditure of local government (APBD) obtained from the website of Directorate general of local givernmant for fiscal balance that consist of budget revenue and expenditure, local revenue (PAD), general allocation fund (DAU), and special allocation fund (DAK). While, for economics growth, this research uses data from BPS report. In addition, multiple regression was used to anylize data by SPSS 17 and path analysis also used to test the hypotheses. This study found that all hipotheses were accepted. The balance fund and local government revenue have positive and significant effects to capital expenditure directly and to economics growth directly and indirectly.
\end{abstract}

Keywords: balance fund, local governmanet revenue, capital expenditure, and economics growth

\begin{abstract}
Abstrak : Penelitian ini bertujuan untuk menguji dan menganalisis pengaruh antara dana perimbangan dan pendapatan asli daerah terhadap pertumbuhan ekonomi melalui belanja modal di Kota dalam Wilayah Jawa Timur mulai tahun 2009 sampai 2014. Sampel penelitian ini ditentukan dengan teknik purposive sampling atau judgement sampling yaitu dengan mengambil data laporan keuangan daerah khusunya data PAD, Belanja Modal, Dana Perimbangan dan Laporan pertumbuhan ekonomi pada periode 2009-2014 pada 8 Kota Di Jawa Timur. Pengambilan data menggunakan data sekunder yang diambil dari Laporan APBD yang diperoleh dari situs Dirjen Perimbangan Keuangan Pemerintah Daerah, yang terdiri dari laporan realisasi anggaran Belanja Modal, Pendapatan Asli Daerah (PAD), Dana Alokasi Umum (DAU), dan Dana Alokasi Khusus (DAK). Sedangkan untuk pertumbuhan ekonomi peneliti mengambil data dari laporan BPS. Selanjutnya, untuk analisis data, penelitian ini menggunakan regresi berganda dengan software SPSS 17, dan untuk pengujian hipotesis digunakan analisis jalur (path analysis).

Penelitian ini menemukan bahwa semua hipotesis dalam penelitian ini terbukti secara positif dan signifikan. Dana Perimbangan dan pendapatan asli daerah mempunyai pengaruh yang positif dan signifikan secara langsung terhadap Belanja modal dan pertumbuhan ekonomi, ataupun tidak langsung melalui mediasi belanja modal terhadap pertumbuhan ekonomi.
\end{abstract}

Kata Kunci: Dana Perimbangan, pendapatan asli daerah, belanja modal, dan pertumbuhan ekonomi 


\section{PENDAHULUAN}

Tujuan utama dari pemberlakuan sistem otonomi daerah adalah untuk meningkatkan kemandirian dan daya saing daerah serta menambah kekuatan fiskal daerah melalui program andalan daerah sehingga mengurangi ketergantuan fiskal terhadap pemerintah pusat. Salah satu upaya yang harus dipersiapkan oleh pemerintah daerah dalam menghadapi otonomi daerah tersebut adalah dengan melakukan strategi penataan pada keuangan daerah dan anggaran daerah. Konsekuensi dari pelaksanaan otonomi daerah adalah pemerintah daerah harus menggali potensi-potensi sumber pendapatan sehingga mampu meningkatkan PAD. PAD adalah sumber penerimaan utama bagi suatu daerah. PAD yang diperoleh suatu daerah berasal dari pajak daerah, retribusi daerah, hasil pengelolaan kekayaan daerah yang dipisahkan, serta lain-lain PAD yang sah.

Selain dari PAD, komponen penerimaan lainnya adalah dana perimbangan yaitu DBH, DAU, dan dana alokasi khusus (DAK). Setiap daerah mempunyai kemampuan keuangan yang tidak sama dalam mendanai kegiatan-kegiatannya, hal ini menimbulkan ketimpangan fiskal antara satu daerah dengan daerah lainnya. Oleh karena itu, untuk mengatasi ketimpangan fiskal ini, pemerintah mengalokasikan dana yang bersumber dari APBN untuk mendanai kebutuhan daerah dalam pelaksanaan desentralisasi. Tujuan utama pemberian dana peimbangan adalah untuk pemerataan fiskal pada tiap daerah (equalizing transfer). Sejak desentralisasi fiskal mulai dilaksanakan pada tahun 2001, dana perimbangan merupakan komponen terbesar dalam alokasi transfer ke daerah sehingga memiliki peranan yang sangat penting dalam mendukung pelaksanaan desentralisasi fiskal.

Belanja modal memiliki peranan penting karena memiliki masa manfaat jangka panjang untuk memberikan pelayanan kepada publik. Alokasi belanja modal ini di dasarkan pada kebutuhan daerah akan sarana dan prasarana, baik untuk kelancaran pelaksanaan tugas pemerintahan maupun untuk fasilitas publik. Belanja modal dimaksudkan untuk mendapatakan aset tetap Pemerintah Daerah, yakni peralatan, bangunan, infrastruktur, dan harta tetap lainnya. Apabila suatu daerah memiliki sarana prasarana yang memadai dapat membuat investor untuk melakukan investasi dan masyarakat dapat melakukan aktivitasnya sehari-hari dengan nyaman sehingga tingkat produktivitas akan semakin meningkat.

Pertumbuhan ekonomi suatu daerah yang meningkat berdampak pada peningkatan pendapatan per kapita penduduk, sehingga tingkat konsumsi dan produktivitas penduduk semakin meningkat. Selain itu, semakin tinggi pendapatan yang diperoleh masyarakat, maka semakin tinggi pula kemampuan masyarakat untuk membayar pungutan yang telah ditetapkan oleh pemerintah daerah. Hal ini akan meningkatkan sumber penerimaan daerah dan tentu saja akan membuat penerimaan PAD semakin tinggi. Peningkatan pertumbuhan ekonomi suatu daerah juga mampu menarik minat investor untuk berinvestasi di daerah sehingga sumber-sumber PAD terutama yang berasal dari pajak daerah akan semakin meningkat. PAD yang tinggi selanjutnya akan digunakan oleh pemerintah daerah untuk memberikan pelayanan publik yang memadai sehingga hal ini akan meningkatkan belanja modal.

Penerimaan PAD Kota di Jawa Timur antara 2009-2015 terus mengalami pertambahan, hal tersebut didukung dengan adanya dana perimbangan dari pemerintah pusat dan diharapkan mampu meningkatkan alokasi belanja modal pemerintah daerah sehingga berdampak pada kualitas pelayanan publik yang semakin baik. Hal tersebut sesuai dengan Instruksi atau Arahan Presiden RI pada Raker Pemerintah Tahun 2012 yang bertema "Tahun Peningkatan Kerja \& Prestasi“" dimana pembahasan memfokuskan pada program efisiensi APBN/APBD. Efisiensi APBN/APBD dilakukan sesuai dengan instruksi presiden dilakukan dengan dua cara yaitu penghematan belanja rutin dan belanja rutin dialihkan ke belanja modal dan infrastruktur. Namun hal tersebut tidak terlihat di Kota di Jawa Timur. Hal tersebut dapat dilihat pada tabel 1.1 di bawah ini:

\section{Efektifitas Dana perimbangan, PAD, dan Belaja Modal}

Efektifitas

\begin{tabular}{llllllll}
\hline Kota & Instrumen & 2009 & 2010 & 2011 & 2012 & 2013 & 2014 \\
\hline \multirow{5}{*}{ Probolinggo } & Dana & 100. & 101. & 101. & 101. & 100. & 100. \\
& perimbangan & $09 \%$ & $44 \%$ & $24 \%$ & $84 \%$ & $24 \%$ & $06 \%$ \\
\cline { 2 - 7 } & Pendapatan & 116. & 114. & 111. & 107. & 100. & 133. \\
& Asli Daerah & $57 \%$ & $47 \%$ & $27 \%$ & $98 \%$ & $80 \%$ & $12 \%$ \\
\cline { 2 - 7 } & Belanja & 96. & 92. & 87. & 95. & 83. & 75. \\
& Modal & $00 \%$ & $00 \%$ & $00 \%$ & $38 \%$ & $41 \%$ & $65 \%$ \\
\hline \multirow{2}{*}{ Sidoarjo } & Dana & 101. & 102. & 102. & 101. & 100. & 100. \\
& perimbangan & $22 \%$ & $44 \%$ & $34 \%$ & $14 \%$ & $30 \%$ & $16 \%$
\end{tabular}




\begin{tabular}{|c|c|c|c|c|c|c|c|}
\hline Kota & Instrumen & 2009 & 2010 & 2011 & 2012 & 2013 & 2014 \\
\hline & $\begin{array}{l}\text { Pendapatan } \\
\text { Asli Daerah }\end{array}$ & $\begin{array}{l}118 . \\
17 \%\end{array}$ & $\begin{array}{l}119 . \\
88 \%\end{array}$ & $\begin{array}{l}116 . \\
11 \%\end{array}$ & $\begin{array}{l}112 . \\
66 \%\end{array}$ & $\begin{array}{l}108 . \\
18 \%\end{array}$ & $\begin{array}{l}123 . \\
22 \%\end{array}$ \\
\hline & $\begin{array}{l}\text { Belanja } \\
\text { Modal }\end{array}$ & $\begin{array}{l}96 . \\
11 \%\end{array}$ & $\begin{array}{l}96 . \\
00 \%\end{array}$ & $\begin{array}{l}94 . \\
44 \%\end{array}$ & $\begin{array}{l}95 . \\
38 \%\end{array}$ & $\begin{array}{l}93 . \\
41 \%\end{array}$ & $\begin{array}{l}89 . \\
65 \%\end{array}$ \\
\hline \multirow{3}{*}{ Kediri } & $\begin{array}{l}\text { Dana } \\
\text { perimbangan }\end{array}$ & $\begin{array}{l}101 . \\
99 \%\end{array}$ & $\begin{array}{l}102 . \\
19 \%\end{array}$ & $\begin{array}{l}101 . \\
14 \%\end{array}$ & $\begin{array}{l}101 . \\
11 \%\end{array}$ & $\begin{array}{l}101 . \\
13 \%\end{array}$ & $\begin{array}{l}101 . \\
11 \%\end{array}$ \\
\hline & $\begin{array}{l}\text { Pendapatan } \\
\text { Asli Daerah }\end{array}$ & $\begin{array}{l}109 . \\
97 \%\end{array}$ & $\begin{array}{l}117 . \\
68 \%\end{array}$ & $\begin{array}{l}114 . \\
91 \%\end{array}$ & $\begin{array}{l}114 . \\
87 \%\end{array}$ & $\begin{array}{l}118 . \\
88 \%\end{array}$ & $\begin{array}{l}118 . \\
39 \%\end{array}$ \\
\hline & $\begin{array}{l}\text { Belanja } \\
\text { Modal }\end{array}$ & $\begin{array}{l}93 . \\
31 \%\end{array}$ & $\begin{array}{l}94 . \\
80 \%\end{array}$ & $\begin{array}{l}95 . \\
98 \%\end{array}$ & $\begin{array}{l}96 . \\
30 \%\end{array}$ & $\begin{array}{l}95 . \\
71 \%\end{array}$ & $\begin{array}{l}95 . \\
85 \%\end{array}$ \\
\hline \multirow{3}{*}{ Madiun } & $\begin{array}{l}\text { Dana } \\
\text { perimbangan }\end{array}$ & $\begin{array}{l}100 . \\
99 \%\end{array}$ & $\begin{array}{l}100 . \\
19 \%\end{array}$ & $\begin{array}{l}101 . \\
14 \%\end{array}$ & $\begin{array}{l}102 . \\
11 \%\end{array}$ & $\begin{array}{l}102 . \\
13 \%\end{array}$ & $\begin{array}{l}96 . \\
98 \%\end{array}$ \\
\hline & $\begin{array}{l}\text { Pendapatan } \\
\text { Asli Daerah }\end{array}$ & $\begin{array}{l}111 . \\
97 \%\end{array}$ & $\begin{array}{l}112 . \\
68 \%\end{array}$ & $\begin{array}{l}114 . \\
91 \%\end{array}$ & $\begin{array}{l}109 . \\
87 \%\end{array}$ & $\begin{array}{l}122 . \\
88 \%\end{array}$ & $\begin{array}{l}125 . \\
39 \%\end{array}$ \\
\hline & $\begin{array}{l}\text { Belanja } \\
\text { Modal }\end{array}$ & $\begin{array}{l}89 . \\
31 \%\end{array}$ & $\begin{array}{l}87 . \\
80 \%\end{array}$ & $\begin{array}{l}91 . \\
98 \%\end{array}$ & $\begin{array}{l}90 . \\
30 \%\end{array}$ & $\begin{array}{l}81 . \\
88 \%\end{array}$ & $\begin{array}{l}85 . \\
63 \%\end{array}$ \\
\hline \multirow{3}{*}{ Jember } & $\begin{array}{l}\text { Dana } \\
\text { perimbangan }\end{array}$ & $\begin{array}{l}101 . \\
00 \%\end{array}$ & $\begin{array}{l}102 . \\
00 \%\end{array}$ & $\begin{array}{l}102 . \\
00 \%\end{array}$ & $\begin{array}{l}101 . \\
00 \%\end{array}$ & $\begin{array}{l}99 . \\
00 \%\end{array}$ & $\begin{array}{l}102 . \\
00 \%\end{array}$ \\
\hline & $\begin{array}{l}\text { Pendapatan } \\
\text { Asli Daerah }\end{array}$ & $\begin{array}{l}102 . \\
00 \%\end{array}$ & $\begin{array}{l}108 . \\
00 \%\end{array}$ & $\begin{array}{l}111 . \\
00 \%\end{array}$ & $\begin{array}{l}115 . \\
00 \%\end{array}$ & $\begin{array}{l}85 . \\
00 \%\end{array}$ & $\begin{array}{l}126 . \\
00 \%\end{array}$ \\
\hline & $\begin{array}{l}\text { Belanja } \\
\text { Modal }\end{array}$ & $\begin{array}{l}88 . \\
00 \%\end{array}$ & $\begin{array}{l}89 . \\
00 \%\end{array}$ & $\begin{array}{l}91 . \\
00 \%\end{array}$ & $\begin{array}{l}93 . \\
00 \%\end{array}$ & $\begin{array}{l}105 . \\
00 \%\end{array}$ & $\begin{array}{l}97 . \\
00 \%\end{array}$ \\
\hline \multirow{3}{*}{ Blitar } & $\begin{array}{l}\text { Dana } \\
\text { perimbangan }\end{array}$ & $\begin{array}{l}101 . \\
22 \%\end{array}$ & $\begin{array}{l}101 . \\
22 \%\end{array}$ & $\begin{array}{l}101 . \\
65 \%\end{array}$ & $\begin{array}{l}103 . \\
99 \%\end{array}$ & $\begin{array}{l}102 . \\
33 \%\end{array}$ & $\begin{array}{l}100 . \\
70 \%\end{array}$ \\
\hline & $\begin{array}{l}\text { Pendapatan } \\
\text { Asli Daerah }\end{array}$ & $\begin{array}{l}97 . \\
88 \%\end{array}$ & $\begin{array}{l}92 . \\
70 \%\end{array}$ & $\begin{array}{l}90 . \\
09 \%\end{array}$ & $\begin{array}{l}89 . \\
29 \%\end{array}$ & $\begin{array}{l}84 . \\
62 \%\end{array}$ & $\begin{array}{l}79 . \\
23 \%\end{array}$ \\
\hline & $\begin{array}{l}\text { Belanja } \\
\text { Modal }\end{array}$ & $\begin{array}{l}113 . \\
49 \%\end{array}$ & $\begin{array}{l}110 . \\
44 \%\end{array}$ & $\begin{array}{l}99 . \\
56 \%\end{array}$ & $\begin{array}{l}121 . \\
07 \%\end{array}$ & $\begin{array}{l}108 . \\
21 \%\end{array}$ & $\begin{array}{l}105 . \\
65 \%\end{array}$ \\
\hline \multirow{3}{*}{ Batu } & $\begin{array}{l}\text { Dana } \\
\text { perimbangan }\end{array}$ & $\begin{array}{l}101 . \\
22 \%\end{array}$ & $\begin{array}{l}103 . \\
22 \%\end{array}$ & $\begin{array}{l}102 . \\
65 \%\end{array}$ & $\begin{array}{l}101 . \\
99 \%\end{array}$ & $\begin{array}{l}103 . \\
33 \%\end{array}$ & $\begin{array}{l}101 . \\
33 \%\end{array}$ \\
\hline & $\begin{array}{l}\text { Pendapatan } \\
\text { Asli Daerah }\end{array}$ & $\begin{array}{l}108 . \\
99 \%\end{array}$ & $\begin{array}{l}108 . \\
67 \% \\
\end{array}$ & $\begin{array}{l}110 . \\
33 \%\end{array}$ & $\begin{array}{l}109 . \\
90 \%\end{array}$ & $\begin{array}{l}115 . \\
11 \%\end{array}$ & $\begin{array}{l}116 . \\
00 \%\end{array}$ \\
\hline & $\begin{array}{l}\text { Belanja } \\
\text { Modal }\end{array}$ & $\begin{array}{l}89 . \\
00 \%\end{array}$ & $\begin{array}{l}91 . \\
00 \%\end{array}$ & $\begin{array}{l}95 . \\
00 \%\end{array}$ & $\begin{array}{l}93 . \\
00 \%\end{array}$ & $\begin{array}{l}95 . \\
00 \%\end{array}$ & $\begin{array}{l}97 . \\
00 \%\end{array}$ \\
\hline \multirow{3}{*}{ Malang } & $\begin{array}{l}\text { Dana } \\
\text { perimbangan }\end{array}$ & $\begin{array}{l}100 . \\
22 \%\end{array}$ & $\begin{array}{l}101 . \\
22 \%\end{array}$ & $\begin{array}{l}102 . \\
15 \%\end{array}$ & $\begin{array}{l}102 . \\
19 \%\end{array}$ & $\begin{array}{l}104 . \\
33 \%\end{array}$ & $\begin{array}{l}102 . \\
63 \%\end{array}$ \\
\hline & $\begin{array}{l}\text { Pendapatan } \\
\text { Asli Daerah }\end{array}$ & $\begin{array}{l}104 . \\
99 \%\end{array}$ & $\begin{array}{l}106 . \\
67 \%\end{array}$ & $\begin{array}{l}112 . \\
33 \%\end{array}$ & $\begin{array}{l}108 . \\
00 \%\end{array}$ & $\begin{array}{l}112 . \\
10 \%\end{array}$ & $\begin{array}{l}106 . \\
00 \%\end{array}$ \\
\hline & $\begin{array}{l}\text { Belanja } \\
\text { Modal }\end{array}$ & $\begin{array}{l}89 . \\
00 \%\end{array}$ & $\begin{array}{l}91 . \\
00 \%\end{array}$ & $\begin{array}{l}92 . \\
00 \%\end{array}$ & $\begin{array}{l}93 . \\
00 \%\end{array}$ & $\begin{array}{l}99 . \\
00 \%\end{array}$ & $\begin{array}{l}101 . \\
00 \%\end{array}$ \\
\hline
\end{tabular}

Perbandingan efektifitas Dana perimbangan, PAD, dan Belaja Modal

Berdasarkan data di atas diketahui bahwa dana perimbangan dan pendapatan asli daerah setiap tahunnya terus mengalami peningkatan antara tahun 2009-2014. Namun tidak demikian dengan belanja modal baik dari sisi jumlah maupun efektifitas. Jumlah belanja modal di Kota pada Wilayah Jawa Timur relative mengalami peningkatan sedangkan secara efektifitas belanja modal cenderung fluktuatif. Peneliti memilih kota-kota dijawa timur terkecuali Kota Surabaya dikarenakan secara geografis maupun administrative serta keuangan memiliki nilai atau jumlah yang berbeda sehingga dapat menimbulkan ketidaknormalan data. Tidak demikian dengan kota - kota selain surabaya yang memiliki luas wilayah menyerupai sama dengan jumlah penduduk yang hampir sama, kota di jawa timur juga memiliki kesamaan dalam sektor ekonomi yaitu yang bergerak dibidang industri dan perdagangan.

Terdapat perbedaan antara penelitian ini dengan penelitian sebelumnya diantaranya adalah variable yang diambil. Dalam penelitian ini variable yang diambil meliputi Dana Perimbangan, Pendapatan Asli Daerah, Belanja Modal dan Pertumbuhan Ekonomi. Variable dalam penelitian yang dilakukan Martini, Cipta dan Suwendra (2014), meliputi Pendapatan Asli Daerah, Dana Alokasi Umum, Dana Alokasi Khusus, dan Belanja Modal. Variable yang digunakan pada penelitian Sugiarthi dan Supadmi (2014) yakni Pendapatan Asli Daerah, Dana Alokasi Umum, SIlpa, Belanja Modal, dan Pertumbuhan Ekonomi. Variabel yang digunakan dalam penelitian Wandira (2013) yani Pendapatan Asli Daerah, Dana Alokasi Umum, Dana Alokasi Khusus, Dana Bagi Hasil, dan Belanja Modal. Selanjutnya variable penelitian yang ditulis oleh Nuarisa (2013) meliputi Pendapatan Asli Daerah, Dana Alokasi Umum, Dana Alokasi Khusus, dan Belanja modal. Selanjutnya variable penelitian yang dilakukan oleh Masdjojo dan Sukartono (2009) yakni Pendapatan Asli Daerah, Dana Perimbangan, dan Belanja Daerah.

\section{HIPOTESIS PENELITIAN \\ Pengaruh Dana Perimbangan terhadap Belanja Modal}

Chang dan Ho (2002) dalam Prakosa (2004), dalam berbagai literatur ekonomi dan keuangan daerah telah mendiskusikan hubungan pendapatan dan belanja daerah secara luas sejak akhir dekade 1950-an. Aziz (2000) dan Doi (1998) dalam Prakosa (2004), menjelaskan bahwa berbagai hipotesis tentang hubungan tersebut telah diuji secara empiris. Sebagian studi menyatakan bahwa pendapatan mempengaruhi belanja dan sebagian lainnya menyatakan bahwa belanjalah yang mempengaruhi pendapatan. Holtz-Eakin et al (1985) dalam Prakosa (2004) menyatakan bahwa terdapat keterkaitan sangat erat antara transfer dari pemerintah dengan belanja daerah. Studi Legrensi dan Milas (2001) dalam Prakosa (2004), menggunakan sample municipalities di Italia, menemukan bukti empiris bahwa dalam jangka penjang transfer berpengaruh terhadap belanja daerah. Secara spesifik mereka menegaskan bahwa variabel-variabel kebijakan 
pemerintah daerah dalam jangka pendek disesuaikan (adjusted) dengan transfer yang diterima, sehingga memungkinkan terjadinya respon yang non-linier dan asymmetric. Sedangkan, Gamkar dan Oates (1996) dalam Prakosa (2004), menganalisa respon pemerintah daerah terhadap perubahan jumlah transfer dari pemerintah federal di Amerika Serikat untuk tahun 1953-1991. Mereka menyatakan bahwa pengurangan jumlah transfer (cults in federal grants) menyebabkan penurunan dalam pengeluaran daerah.

Selanjutnya, penelitian yang dilakukan oleh Jaya dan Dwirandra (2014) dengan judul Pengaruh Pendapatan Asli Daerah Pada Belanja Modal Dengan Pertumbuhan Ekonomi Sebagai Variabel Pemoderasi. Tujuan dari penelitian ini yaitu untuk mengetahui adanya pengaruh pendapatan asli daerah pada belanja modal dengan pertumbuhan ekonomi sebagai variabel pemoderasi. Berdasarkan hasil analisis diperoleh bahwa pendapatan asli daerah berpengaruh positif dan signifikan pada belanja modal, pertumbuhan ekonomi tidak berpengaruh signifikan pada belanja modal, serta pertumbuhan ekonomi berpengaruh signifikan dan mampu memoderasi pengaruh pendapatan asli daerah pada belanja modal tetapi dengan intensitas dan arah yang berlawanan.

H1: Dana perimbangan berpengaruh terhadap belanja modal.

\section{Pengaruh Dana Perimbangan terhadap Pertumbuhan Ekonomi}

Perimbangan keuangan antara pusat dan daerah merupakan suatu sistem hubungan keuangan yang bersifat vertikal antara pemerintah pusat dan daerah (intergovernmental fiscal relation system), sebagai konsekuensi dari pelaksanaan otonomi daerah dalam bentuk penyerahan sebagian wewenang pemerintah. Sistem pembiayaan penyelenggaraan pemerintah pusat dan daerah ini diatur dalam UU Nomor 33 Tahun 2004.

Penelitian yang dilakukan oleh Ristriardani (2011) menemukan bahwa DAU, DBH dan DBH PU mempunyai hubungan yang positif dan signifikan dengan pendapatan perkapita Kabupaten/Kota di Provinsi Kalimantan Selatan. Sedangkan, DAK menunjukkan hasil yang tidak signifikan sehingga tidak dapat diambil kesimpulan untuk menjelaskan pengaruhnya terhadap pendapatan perkapita. Hasil penelitian lainnya adalah terdapat disparitas pendapatan perkapita antar daerah Kabupaten/Kota di Provinsi Kalimantan Selatan periode tahun 2001 s. d 2008. DBH dan DBH PU mendorong terjadinya tingkat disparitas yang tinggi, namun DAU (yang mempunyai tujuan mengurangi kesenjangan pendapatan) mampu mengurangi tingkat disparitas pendapatan antar daerah tersebut.

H2: Dana Perimbangan berpengaruh terhadap pertumbuhan ekonomi

\section{Pengaruh Pendapatan Asli Daerah terhadap Belanja Modal}

Menurut Robert (2004) Pendapatan Asli Daerah (PAD) berpengaruh terhadap Dana Alokasi Umum (DAU), karena adanya DAU bagi pemerintah daerah merupakan sumber pendanaan dalam melaksanakan kewenangannya, sedangkan kekurangan pendanaan diharapkan dapat digali melalui sumber pendanaan sendiri yaitu PAD. Darise (2008) Dana Alokasi Umum (DAU) berpengaruh terhadap Dana Alokasi Khusus (DAK). DAU diharapkan menjadi modal dalam rangka menciptakan pemanfaatan yang lebih baik sedangkan DAK untuk membantu mendanai kegiatan khusus yang merupakan urusan daerah dan sesuai dengan prioritas nasional.

Selanjutnya dalam penelitian lain, Martini, dkk (2014) menemukan bahwa ada pengaruh positif dan signifikan antara Pendapatan Asli Daerah, Dana Alokasi Umum dan Dana Alokasi Khusus dengan Belanja Modal, antara Pendapatan Asli Daerah dengan Belanja Modal, antara Dana Alokasi Umum dengan Belanja Modal, antara Dana Alokasi Khusus dengan Belanja Modal, antara Pendapatan Asli Daerah dengan Dana Alokasi Umum, dan antara Dana Alokasi Umum dengan Dana Alokasi Khusus.

H3: pendapatan asli daerah berpengaruh terhadap belanja modal

\section{Pengaruh pendapatan asli daerah terhadap pertumbuhan ekonomi}

Mardiasmo (2002: 132) menyatakan "pendapatan Asli Daerah adalah penerimaan yang diperoleh dari sektor pajak daerah, retribusi daerah, hasil perusahaan milik daerah, hasil pengelolaan kekayaan daerah yang dipisahkan, dan lain-lain pendapatan asli daerah yang sah". Dipihak lain Nurcholis (2007: 182), menyatakan bahwa "pendapatan asli daerah adalah pendapatan yang diperoleh dari hasil pajak daerah, hasil retribusi daerah, laba 
perusahaan daerah, dan lain-lain yang sah". Sedangkan Herlina Rahman (2005: 38) "pendapatan asli daerah merupakan pendapatan daerah yang bersumber dari hasil pajak daerah, hasil distribusi hasil pengelolaan kekayaan daerah yang dipisahkan dan lain-lain pendapatan asli daerah yang sah dalam menggali pendanaan dalam pelaksanaan otonomi daerah sebagai perwujudan asas desentralisasi. Sumber-sumber PAD sebagaimana diatur dalam UndangUndang No. 32 Tahun 2004 Pasal 157 adalah (1) pajak daerah, (2) retribusi daerah, (3) Perusahaan Daerah, dan (4) pendapatan asli daerah yang sah.

Penelitian yang dilakukan oleh Wandira (2013) dengan judul penelitian Pengaruh pendapatan asli daerah (PAD), dana alokasi umum (DAU), dana alokasi khusus (DAK), dan dana bagi hasil (DBH) terhadap pengalokasian Belanja modal. menyimpulkan bahwa secara parsial variabel DAU dengan arah negatif, DAK dan DBH berpengaruh signifikan terhadap belanja modal. Sedangkan PAD tidak berpengaruh signifikan terhadap belanja modal. Secara simultan variabel PAD, DAU, DAK, dan DBH berpengaruh signifikan terhadap belanja modal.

H4: Pendapatan asli daerah berpengaruh terhadap pertumbuhan ekonomi

\section{Pengaruh Belanja Modal Terhadap Pertumbuhan Ekonomi}

Pertumbuhah ekonomi merupakan parameter dari suatu kegiatan pembangunan, hal ini dikarenakan pertumbuhan ekonomi dapat mengukur tingkat perkembangan aktivitas pada sektor-sektor ekonomi dalam suatu perekonomian. Parameter tersebut menjadi landasan dalam mengambil keputusan dan kebijaksanaan dasar oleh pemerintah untuk meningkatkan kegiatan ekonomi. Salah satu faktor yang dapat menunjang pertumbuhan ekonomi adalah tersedianya dana untuk pembangunan yang dapat di ambil dari belanja modal.

Belanja modal berperan penting dalam meningkatkan pertumbuhan ekonomi. Beberpa hasil penelitian menunjukkan bahwa belanja modal memiliki pengaruh terhadap pertumbuhan ekonomi. Penelitian Lukman Hakim, Anita Wijayanti (2014) menunjukkan bahwa belanja modal yang terdiri dari (1) belanja modal tanah, (]2) belanja modal peralatan dan mesin, (3) belanja modal gedung dan bangunan, (4) belanja modal jalan, irigasi, dan jaringan, dan (5) belanja modal lainnya, memiliki pengaruh positif terhadap pertumbuhan ekonomi yang dapat dilihat dari Produk Domestik Regional Bruto (PDRB) sebagai representasi dari pertumbuhan ekonomi.

H5: Belanja Modal berpengaruh terhadap Pertumbuhan Ekonomi

\section{Pengaruh Dana Perimbangan Terhadap Pertumbuhan Ekonomi Melalui Belanja Modal}

Menurut Susanti dkk, (2000: 23) bahwa pertumbuhan ekonomi menunjukkan sejauh mana aktivitas perekonomian akan menghasilkan tambahan pendapatan masyarakat pada suatu periode tertentu. Menurut Michel P. Todaro (2004: 92), terdapat tiga faktor atau komponen utama dalam pertumbuhan ekonomi dari setiap bangsa, yaitu akumulasi modal, pertumbuhan penduduk, kemajuan teknologi. Proses kenaikan output per kapita diproksi dengan Produk Domestik Regional Bruto (PDRB) per Kapita yang didefinisikan sebagai jumlah nilai tambah yang dihasilkan oleh seluruh unit usaha dalam suatu wilayah, atau merupakan jumlah seluruh nilai barang dan jasa akhir yang dihasilkan oleh seluruh unit ekonomi di suatu daerah. Akumulasi modal yang digunakan untuk pelaksanaan pembangunan dapat dipengaruhi oleh dana perimbangan yang merupakan salah satu modal pembangunan. Sehigga dari model ini dapat di konstruksikan bahwa belanja modal dapat menjadi variabel intervening antara dana perimbangan dan pertumbuhan ekonomi.

Hasil penelitian $\mathrm{Ni}$ Made Nopiani, Wayan Cipta, Fridayana Yudiaatmaja (2016) menjelaskan bahwa terdapat pengaruh positif dana perimbangan terhadap pertumbuhan ekonomi dimana belanja modal sebagai variabel intervening. Hubungan positif yang kuat antara dana perimbangan dengan belanja modal ini dapat dipahami mengingat bahwa pelaksanaan otonomi daerah yang bertujuan untuk meningkatkan pelayanan publik yang direalisasikan melalui belanja modal juga ikut dibiayai oleh dana perimbangan tersebut. Dengan semakin tingginya pelayanan dan pembangunan maka pertumbuhan ekonomi suatu daerah tentunya juga akan semakin meningkat.

H6: Dana Perimbangan berpengaruh terhadap Pertumbuhan Ekonomi Melalui Belanja Modal 


\section{Pendapatan Asli Daerah Terhadap Pertumbuhan Ekonomi Melalui Belanja Modal}

PAD yang tinggi akan mempengaruhi pembangunan dan perkembangan di daerah yang direalisasikan dalam bentuk pengadaan fasilitas, infrastruktur, dan sarana prasarana yang ditujukan untuk kepentingan publik, sehingga hal ini akan meningkatkan alokasi belanja modal. Hasil ini mendukung penelitian oleh Tuasikal (2008). Belanja modal yang dilakukan oleh pemerintah daerah untuk pengadaan sarana prasarana, fasilitas serta infrastruktur bertujuan untuk meningkatkan pertumbuhan ekonomi daerah. Ketika suatu daerah menginginkan peningkatan pertumbuhan ekonomi, maka pemerintah daerah akan menambah pengalokasian belanja modalnya dengan mengambil dari pendapatan asli daerahnya. Hal ini karena tujuan pemerintah daerah melakukan belanja modal yaitu untuk peningkatan pertumbuhan. Dari konstruksi tersebut dapat dibentuk bahwa belanja modal dapat menjadi variabel intervening antara PAD dan pertumbuhan ekonomi.

Hasil penelitian I Putu Ngurah Panji Kartika Jaya (2014) menunjukkan bahwa terdapat pengaruh Pendapatan Asli daerah terhadap pertumbuhan ekonomi melalui belanja modal sebagai variabel intervening. Hal ini membuktikan bahwa semakin tinggi PAD yang dialokasikan terhadap belanja modal maka akan semkin tinggi pula kegiatan pembangunan yang dapat menunjang pertumbuhan ekonomi suatu daerah.

H7: Pendapatan Asli Daerah berpengaruh terhadap Pertumbuhan Ekonomi Melalui Belanja Modal

\section{Kerangka Konsep Penelitian}

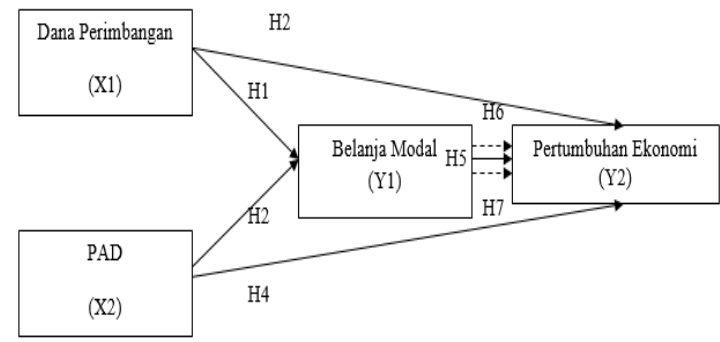

\section{METODE}

Pendekatan dalam penelitian ini adalah pendekatan kuantitatif dan masuk dalam kategori explanatory research (penelitian penjelasan). Populasi dalam penelitian ini merupakan keseluruhan laporan keuangan daerah Di Kota yang ada di Wilayah Jawa Timur (kecuali Kota Surabaya) pasca era otonomi daerah yang memuat PAD, Belanja Modal, Dana Perimbangan dan Laporan pertumbuhan ekonomi dari BPS. Peneliti mengampil sampel dengan teknik purposive sampling atau judgement sampling yaitu dengan mengambil data laporan keuangan daerah khusunya data PAD, Belanja Modal, Dana Perimbangan dan Laporan pertumbuhan ekonomi pada periode 2009-2014 pada 8 Kota Di Jawa Timur. Analisis data dalam penelitian ini menggunakan regresi berganda dan dianalisis menggunakan SPSS 17. Sedangkan untuk menguji hipotesis digunakan teknik analisis jalur (path analysis).

\section{HASIL PENELITIAN}

Berdasarkan data yang didapat dilapangan, sebelum dilakukan analisis dan pengujian terhadap semua hipotesis, langkah pertama peneliti melakukan uji asumsi klasik untuk mengetahui suatu model regresi (pengaruh) yang benar-benar mampu memberikan estimasi yang tidak bias atau handal (Ghozali, 2006: 110). Uji Asumsi Klasik dalam penelitian ini dilakukan dengan tiga uji yaitu uji normalitas, uji multikolinieritas dan uji heteroskedastisitas.

Berdasarkan hasil analisis data terkait hasil uji asumsi klasik didapat; pertama untuk uji normalitas, seluruh variabel memiliki data dengan sig. Z lebih besar dari nilai alpha 0.05. Kedua, untuk uji Multikolinearitas, semua variabel mempunyai nilai diatas 0,1 untuk nilai tolerance dan dibawah 10 untuk nilai VIF. Ketiga, untuk uji heterokedastisitas, dari grafik Scatterplot, tidak ditemukan terbentuknya polapola tertentu dari penyebaran titik-titik pada grafik. Oleh karena itu, dari semua uji asumsi klasik dapat disimpulkan bahwa seluruh data pada tiap variabel terdistribusi secara normal, model regresi dalam penelitian ini adalah homoskedastisitas atau tidak terjadi heteroskedastisitas, dan di antara variabel independen dinyatakan bebas dari multikolinearitas.

\section{Hasil Analisis Jalur}

Analisis jalur dilakukan untuk melihat pengaruh antar variabel dengan melihat taraf signifikasi antar variabel, serta hubungan antar variabel. Hasil analisis data ditunjukan pada tabel dan gambar dibawah ini. 


\begin{tabular}{lllll}
$\begin{array}{c}\text { Ringkasan Koefisien Jalur } \\
\text { Variabel } \\
\text { Eksogen }\end{array}$ & $\begin{array}{c}\text { Varabel } \\
\text { Indogen }\end{array}$ & $\begin{array}{c}\text { Koefisien } \\
\text { Beta }\end{array}$ & $\begin{array}{c}\text { P- } \\
\text { Value }\end{array}$ & Kesimpulan \\
\hline $\begin{array}{l}\text { Dana } \\
\text { Perimbangan }\end{array}$ & $\begin{array}{l}\text { Belanja } \\
\text { Modal }\end{array}$ & 0.230 & 0.043 & Signifikan \\
\hline $\begin{array}{l}\text { Dana } \\
\text { Perimbangan }\end{array}$ & $\begin{array}{l}\text { Pertumbuhan } \\
\text { Ekonomi }\end{array}$ & 0.262 & 0.048 & Signifikan \\
\hline $\begin{array}{l}\text { Pendapatan } \\
\text { Asli Daerah }\end{array}$ & $\begin{array}{l}\text { Belanja } \\
\text { Modal }\end{array}$ & 0.605 & 0,000 & Signifikan \\
\hline $\begin{array}{l}\text { Pendapatan } \\
\text { Asli Daerah }\end{array}$ & $\begin{array}{l}\text { Pertumbuhan } \\
\text { Ekonomi }\end{array}$ & 0.497 & 0,003 & Signifikan \\
\hline $\begin{array}{l}\text { Belanja } \\
\text { Modal }\end{array}$ & $\begin{array}{l}\text { Pertumbuhan } \\
\text { Ekonomi }\end{array}$ & 0.205 & 0,015 & Signifikan \\
\hline Sumber: Data Peneliti SPSS, 2016 &
\end{tabular}

Sumber: Data Peneliti SPSS, 2016

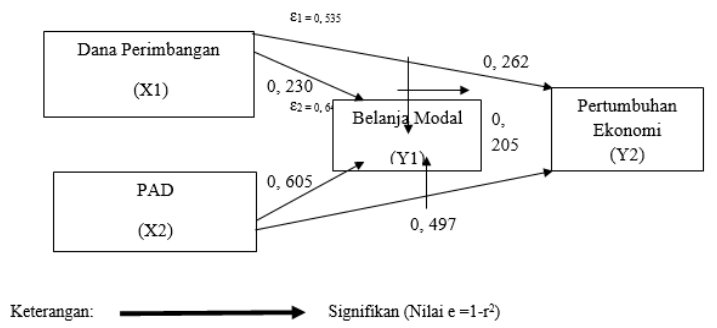

Berdasarkan tabel dan gambar diatas menunjukkan bahwa; pertama, pengaruh variabel dana perimbangan (X1) terhadap variabel belanja modal (Y1) menunjukkan $t$ hitung sebesar 2, 084, nilai p-value sebesar 0 , 043 dan koefisien (beta) sebesar 0, 230 . Hasil uji t menggambarkan bahwa thitung lebih besar $\mathrm{t}$ tabel $(2,084>1,67722)$ dan $\mathrm{p}$-value lebih kecil dari signifikan $(0,043)$. Sedangkan, nilai koefisien jalur (beta) memiliki angka positif, maka hasilnya adalah signifikan dan positif. Hal ini dapat disimpulkan bahwa variabel belanja modal (Y1) dapat dijelaskan secara langsung oleh variabel dana perimbangan (X1). Kedua, pengaruh variabel pendapatan asli daerah (X2) terhadap variabel belanja modal (Y1) mempunyai nilai t hitung sebesar $(5,469>1$, 67722), nilai p-value sebesar $(0,000<0,005)$ dan koefisien jalur (beta) sebesar 0, 605. Hasil ini dapat disimpulkan bahwa pengaruh kedua variabel adalah positif dan signifikan dan variabel belanja modal (Y1) dapat dijelaskan secara langsung oleh variabel pendapatan asli daerah (X2). Ketiga, pengaruh variabel dana perimbangan (X1) terhadap variabel pertumbuhan ekonomi (Y2) menunjukkan t hitung lebih besar dari pada $t$ tabel dengan nilai 2, 036, dan nilai p-value lebih kecil dari nilai signifikan dengan nilai 0,048 dan nilai koefisien jalur (beta) sebesar 0, 262. Dengan demikian dapat disimpulkan bahwa hasilnya adalah signifikan dan positif. Hasil ini menunjukkan bahwa variabel pertumbuhan ekonomi (Y2) dapat dijelaskan secara langsung oleh variabel dana perimbangan $(\mathrm{X} 1)$ dan

Keempat, pengaruh pendapatan Asli Daerah (X2) terhadap variabel pertumbuhan Ekonomi (Y2) menunjukkan thitung sebesar (3, 139>1, 67722), nilai p-value lebih kecil dari nilai signifikansi $(0,003<0,05)$ dan koefisien jalur (beta) sebesar 0, 497 yang berarti positif dan signifikan. Dengan demikian, hasil ini bermakna bahwa variabel pertumbuhan ekonomi (Y2) dapat dijelaskan secara langsung oleh variabel pendapatan Asli Daerah (X2). Kelima, pengaruh variabel kepuasan kerja belanja modal (Y1) terhadap variabel pertumbuhan ekonomi (Y2) menunjukkan nilai t hitung lebih besar dari $t$ tabel $(2,032>1,67722)$ dan p-value lebih kecil dari nilai signifikansi $(0$, $015<0,05$ ), serta koefisien jalur (beda) memiliki angka positif, maka hasilnya adalah signifikan dan positif. Hasil ini dapat disimpulkan menunjukkan bahwa variabel pertumbuhan ekonomi (Y2) dapat dijelaskan langsung oleh variabel belanja modal (Y1).

Untuk mengetahui pengaruh tidak langsung antara variabel dependen dan independen melalui variabel mediasi, hasil perhitungan statistiknya sebagaimana tabel berikut:

\section{Hasil Pengujian Hubungan Langsung dan Tidak Langsung}

\begin{tabular}{cll}
\hline $\begin{array}{c}\text { Pengaruh } \\
\text { Variabel }\end{array}$ & $\begin{array}{c}\text { Pengaruh } \\
\text { Langsung }\end{array}$ & \multicolumn{1}{c}{$\begin{array}{c}\text { Pengaruh Tidak Langsung } \\
\text { Melalui Y1 }\end{array}$} \\
\hline X1 terhadap Y1 & 0.230 & - \\
\hline X1 terhadap Y2 & 0.262 & $\begin{array}{l}(0.262) \times(0.205)=0.05315 \\
\text { (signifikan) }\end{array}$ \\
\hline X2 terhadap Y1 & 0.605 & - \\
\hline X2 terhadap Y2 & 0.497 & $\begin{array}{l}(0.497) \times(0.205)=0.101885 \\
\text { (signifikan) }\end{array}$ \\
\hline
\end{tabular}

Y1 terhadap Y2 0. 205

Tabel diatas menunjukan bahwa pengaruh tidak langsung antara variabel dana perimbangan (X1) dengan pertumbuhan ekonomi (Y2) yang dimediasi oleh belanja modal (Y1) mempunyai nilai 0, 05315 yang berarti juga signifikan. Hasil yang kurang lebih sama juga terjadi pada nilai pengaruh tidak langsung antara variabel pendapatan asli daerah (X2) dengan pertumbuhan ekonomi (Y2) melalui belanja modal (Y1) yang mana hasilnya sebesar 0, 101885 yaitu juga berarti signifikan. Oleh karena itu, berdasarkan penjelasan diatas semua hipotesis dalam penelitian ini diterima. 
PEMBAHASAN

\section{Pengaruh Dana Perimbangan terhadap Belanja Modal}

Belanja modal digunakan untuk mendapatakan aset tetap Pemerintah Daerah seperti peralatan, bangunan, infrastruktur, dan harta tetap lainnya. Secara teoritis ada tiga cara untuk memperoleh aset tetap tersebut, yakni dengan membangun sendiri, menukarkan dengan aset tetap lain, dan membeli. Namun, untuk di pemerintahan, biasanya cara yang dilakukan adalah dengan cara membeli melalui lelang atau tender (Widjaja, 2002).

Hasil penelitian ini sesuai dengan penelitian dari Chang dan Ho (2002) dalam Prakosa (2004), dalam berbagai literatur ekonomi dan keuangan daerah telah mendiskusikan hubungan pendapatan dan belanja daerah secara luas sejak akhir dekade 1950-an. Aziz (2000) dan Doi (1998) dalam Prakosa (2004), menjelaskan bahwa berbagai hipotesis tentang hubungan tersebut telah diuji secara empiris. Sebagian studi menyatakan bahwa pendapatan mempengaruhi belanja dan sebagian lainnya menyatakan bahwa belanjalah yang mempengaruhi pendapatan.

\section{Pengaruh Pendapatan Asli Daerah (PAD) terhadap Belanja Modal}

Pengalokasian belanja modal ditujukan untuk meningkatkan kualitas pelayanan publik melalui peningkatan aset tetap pemerintah daerah, yakni peralatan, bangunan, infrastruktur, dan harta tetap lainnya (Darwanto \& Yulia, 2007). Pemerintah daerah setiap tahun mengalokasikan belanja modal baik untuk mengganti aset lama maupun pembelian aset baru sehingga asset pemerintah daerah bertambah nilainya dari tahun ke tahun (Rustiyaningsih, 2012). Sehingga dapat dikatakan aset tetap pemerintah daerah yang bersumber dari pelaksanaan APBD merupakan output/outcome dari terealisasinya belanja modal dalam setiap tahun anggarannya (Abdullah \& Halim, 2006).

Peningkatan aset Pemerintah Daerah semestinya juga semakin meningkatkan belanja pemeliharaan terhadap aset tersebut dari tahun ke tahun meskipun mungkin peningkatan keduanya tidaklah proporsional, karena pengalokasian belanja modal berhubungan dengan pengalokasian belanja pemeliharaan terhadap aset (Rustiyaningsih, 2012).

Sehingga dapat disimpulkan bahwa dengan adanya kenaikan realisasi anggaran pada
Pendapatan Asli Daerah (PAD) Pemerintah Kota di Jawa Timur selama 4 tahun terakhir harus diimbangi dengan kenaikan realisasi anggaran belanja modalnya, terutama pada pos belanja modal jalan, irigasi dan jaringan agar masalah mengenai penyediaan air bersih yang terjadi hampir setiap tahun dapat diatasi. Disamping itu dengan meningkatnya anggaran untuk belanja modal maka dapat menyediakan fasilitas, sarana dan prasarana umum agar tercapainya kesejahteraan masyarakat.

\section{Pengaruh Dana Perimbangan terhadap Pertumbuhan Ekonomi}

Perimbangan keuangan antara pusat dan daerah merupakan suatu sistem hubungan keuangan yang bersifat vertikal antara pemerintah pusat dan daerah (intergovernmental fiscal relation system), sebagai konsekuensi dari pelaksanaan otonomi daerah dalam bentuk penyerahan sebagian wewenang pemerintah. Sistem pembiayaan penyelenggaraan pemerintah pusat dan daerah ini diatur dalam UU Nomor 33 Tahun 2004.

Penelitian yang dilakukan oleh Ristriardani (2011) dengan judul penelitian Pengaruh Dana Perimbangan Terhadap Pendapatan Perkapita dan Disparitas Pendapatan Antar Daerah di Provinsi Kalimantan Selatan. Penelitian ini bertujuan untuk mengetahui pengaruh Dana Perimbangan terhadap disparitas pendapatan perkapita antar daerah Kabupaten/Kota di Provinsi Kalimantan Selatan. Penelitian ini menggunakan data sekunder dan metode analisis yang digunakan adalah analisis deskriptif dan inferensial. Hasil penelitian menunjukkan bahwa DAU, DBH dan DBH PU mempunyai hubungan yang positif dan signifikan dengan pendapatan perkapita Kabupaten/Kota di Provinsi Kalimantan Selatan sedangkan DAK menunjukkan hasil yang tidak signifikan sehingga tidak dapat diambil kesimpulan untuk menjelaskan pengaruhnya terhadap pendapatan perkapita. Hasil penelitian lainnya adalah terdapat disparitas pendapatan perkapita antar daerah Kabupaten/Kota di Provinsi Kalimantan Selatan periode tahun 2001 s. d 2008. DBH dan DBH PU mendorong terjadinya tingkat disparitas yang tinggi, namun DAU (yang mempunyai tujuan mengurangi kesenjangan pendapatan) mampu mengurangi tingkat disparitas pendapatan antar daerah tersebut. 


\section{Pengaruh Pendapatan Asli Daerah Terhadap Pertumbuhan Ekonomi}

Dalam hal pendapatan asli daerah Mardiasmo (2002: 132) menyatakan "pendapatan Asli Daerah adalah penerimaan yang diperoleh dari sektor pajak daerah, retribusi daerah, hasil perusahaan milik daerah, hasil pengelolaan kekayaan daerah yang dipisahkan, dan lain-lain pendapatan asli daerah yang sah". Dipihak lain Nurcholis (2007: 182), menyatakan bahwa "pendapatan asli daerah adalah pendapatan yang diperoleh dari hasil pajak daerah, hasil retribusi daerah, laba perusahaan daerah, dan lain-lain yang sah". Sedangkan Herlina Rahman (2005: 38) "pendapatan asli daerah merupakan pendapatan daerah yang bersumber dari hasil pajak daerah, hasil distribusi hasil pengelolaan kekayaan daerah yang dipisahkan dan lain-lain pendapatan asli daerah yang sah dalam menggali pendanaan dalam pelaksanaan otonomi daerah sebagai perwujudan asas desentralisasi. Sumber-sumber PAD sebagaimana diatur dalam UndangUndang No. 32 Tahun 2004 Pasal 157 adalah (1) pajak daerah, (2) retribusi daerah, (3) Perusahaan Daerah, dan (4) pendapatan asli daerah yang sah.

Temuan ini sejalan dengan penelitian yang dilakukan oleh Wandira (2013) yang menemukan bahwa secara parsial variabel DAU dengan arah negatif, DAK dan DBH berpengaruh signifikan terhadap belanja modal. Sedangkan PAD tidak berpengaruh signifikan terhadap belanja modal. Secara simultan variabel PAD, DAU, DAK, dan DBH berpengaruh signifikan terhadap belanja modal.

\section{Pengaruh Belanja Modal terhadap Pertumbuhan Ekonomi}

Pertumbuhah ekonomi merupakan parameter dari suatu kegiatan pembangunan, hal ini dikarenakan pertumbuhan ekonomi dapat mengukur tingkat perkembangan aktivitas pada sektor-sektor ekonomi dalam suatu perekonomian. Parameter tersebut menjadi landasan dalam mengambil keputusan dan kebijaksanaan dasar oleh pemerintah untuk meningkatkan kegiatan ekonomi. Salah satu faktor yang dapat menunjang pertumbuhan ekonomi adalah tersedianya dana untuk pembangunan yang dapat di ambil dari belanja modal.

Belanja modal berperan penting dalam meningkatkan pertumbuhan ekonomi. Beberpa hasil penelitian menunjukkan bahwa belanja modal memiliki pengaruh terhadap pertumbuhan ekonomi. Penelitian Lukman Hakim, Anita Wijayanti (2014) menunjukkan bahwa belanja modal yang terdiri dari (1) belanja modal tanah, (2) belanja modal peralatan dan mesin, (3) belanja modal gedung dan bangunan, (4) belanja modal jalan, irigasi, dan jaringan, dan (5) belanja modal lainnya, memiliki pengaruh positif terhadap pertumbuhan ekonomi yang dapat dilihat dari Produk Domestik Regional Bruto (PDRB) sebagai representasi dari pertumbuhan ekonomi.

\section{Pengaruh Dana Perimbangan terhadap Pertumbuhan Ekonomi Melalui Belanja Modal}

Menurut Susanti dkk, (2000: 23) bahwa pertumbuhan ekonomi menunjukkan sejauh mana aktivitas perekonomian akan menghasilkan tambahan pendapatan masyarakat pada suatu periode tertentu. Menurut Michel P. Todaro (2004: 92), terdapat tiga faktor atau komponen utama dalam pertumbuhan ekonomi dari setiap bangsa, yaitu akumulasi modal, pertumbuhan penduduk, kemajuan teknologi. Proses kenaikan output per kapita diproksi dengan Produk Domestik Regional Bruto (PDRB) per Kapita yang didefinisikan sebagai jumlah nilai tambah yang dihasilkan oleh seluruh unit usaha dalam suatu wilayah, atau merupakan jumlah seluruh nilai barang dan jasa akhir yang dihasilkan oleh seluruh unit ekonomi di suatu daerah. Akumulasi modal yang digunakan untuk pelaksanaan pembangunan dapat dipengaruhi oleh dana perimbangan yang merupakan salah satu modal pembangunan. Sehigga dari model ini dapat di konstruksikan bahwa belanja modal dapat menjadi variabel intervening antara dana perimbangan dan pertumbuhan ekonomi.

Hasil penelitian $\mathrm{Ni}$ Made Nopiani, Wayan Cipta, Fridayana Yudiaatmaja (2016) menjelaskan bahwa terdapat pengaruh positif dana perimbangan terhadap pertumbuhan ekonomi dimana belanja modal sebagai variabel intervening. Hubungan positif yang kuat antara dana perimbangan dengan belanja modal ini dapat dipahami mengingat bahwa pelaksanaan otonomi daerah yang bertujuan untuk meningkatkan pelayanan publik yang direalisasikan melalui belanja modal juga ikut dibiayai oleh dana perimbangan tersebut. Dengan semakin tingginya pelayanan dan pembangunan maka pertumbuhan ekonomi 
suatu daerah tentunya juga akan semakin meningkat.

\section{Pengaruh Pendapatan Asli Daerah Terhadap Pertumbuhan ekonomi melalui belanja modal}

PAD yang tinggi akan mempengaruhi pembangunan dan perkembangan di daerah yang direalisasikan dalam bentuk pengadaan fasilitas, infrastruktur, dan sarana prasarana yang ditujukan untuk kepentingan publik, sehingga hal ini akan meningkatkan alokasi belanja modal. Hasil ini mendukung penelitian oleh Tuasikal (2008). Belanja modal yang dilakukan oleh pemerintah daerah untuk pengadaan sarana prasarana, fasilitas serta infrastruktur bertujuan untuk meningkatkan pertumbuhan ekonomi daerah. Ketika suatu daerah menginginkan peningkatan pertumbuhan ekonomi, maka pemerintah daerah akan menambah pengalokasian belanja modalnya dengan mengambil dari pendapatan asli daerahnya. Hal ini karena tujuan pemerintah daerah melakukan belanja modal yaitu untuk peningkatan pertumbuhan. Dari konstruksi tersebut dapat dibentuk bahwa belanja modal dapat menjadi variabel intervening antara PAD dan pertumbuhan ekonomi.

Hasil penelitian I Putu Ngurah Panji Kartika Jaya (2014) menunjukkan bahwa terdapat pengaruh Pendapatan Asli daerah terhadap pertumbuhan ekonomi melalui belanja modal sebagai variabel intervening. Hal ini membuktikan bahwa semakin tinggi PAD yang dialokasikan terhadap belanja modal maka akan semkin tinggi pula kegiatan pembangunan yang dapat menunjang pertumbuhan ekonomi suatu daerah.

Penelitian ini hanya menggunakan data sekunder yang terdiri dari 6 kota di wilayah Provinsi Jawa Timur sehingga hasil penelitian ini hanya bisa diterapkan pada provinsi yang memiliki karakteristik sama tetapi untuk provinsi lainnya dengan karakteristik yang berbeda ada kemungkinan tidak dapat diterapkan.

\section{KESIMPULAN}

Berdasarkan pengolahan data, hasil analisis dan pembahasan baik secara statistik maupun pembahasan komprehensif berdasar fakta empiris, kajian teori maupun peraturan terkait, dapat ditarik beberapa kesimpulan dari penelitian ini sebagai berikut: pertama, Dana perimbangan didapatkan hasil berpengaruh signifikan terhadap belanja modal. Kedua, Pendapatan asli daerah (PAD) berpengaruh signifikan terhadap belanja modal. Ketiga, Dana perimbangan berpengaruh siginifikan terhadap pertumbuhan ekonomi. Keempat, Pendapatan asli daerah (PAD) berpengaruh signifikan terhadap pertumbuhan. Kelima, Belanja modal berpengaruh signifikan terhadap pertumbuhan ekonomi. Keenam, Dana perimbangan berpengaruh signifikan terhadap pertumbuhan ekonomi melalui belanja modal. Ketujuh, Pendapatan asli daerah berpengaruh signifikan terhadap pertumbuhan ekonomi melalui belanja modal.

Beberapa saran yang bisa diberikan kepada beberapa pihak, diantaranya, pertama, sebagai bahan evaluasi dan rekomendasi untuk pemerintah pusat maupun pemerintah daerah dalam pembuatan kebijakan berkaitan dengan penggunaan anggaran berasal dari pendapatan asli daerah. Kedua, pengunaan dana seperti DAU dan DAK harus lebih diorientasikan pada efektivitas program yang dapat secara langsung mensejahterakan masyarakat. Ketiga, sebagai tambahan referensi bagi penelitian selanjutnya yang berkaitan dengan PAD, Dana Perimbangan, pertumbuhan ekonomi, dan Belanja Modal.

\section{DAFTAR PUSTAKA}

Abdullah, Sukriy dan Halim, Abdul. 2003. Pengaruh Dana Alokasi Umum (DAU) dan Pendapatan Asli Daerah (PAD) terhadap Belanja Pemerintah Daerah Studi Kasus Kabupaten/Kota di Jawa dan Bali.Simposium Nasional Akuntansi VI, Yogyakarta.

Darwanto dan Yulia Yustikasari. 2007. Pengaruh Pertumbuhan Ekonomi, Pendapatan Asli Daerah dan Dana Alokasi Umum Terhadap Pengalokasian Anggaran Belanja Modal. Makalah Simposium Nasional Akuntansi (SNA) X, Makassar.

Halim, Abdul \& Syukriy Abdullah. 2006. Hubungan dan masalah keagenan di pemerintahan daerah: sebuah peluang penelitian anggaran dan akuntansi. Jurnal Akuntansi Pemerintah 2 (1): 53-64.

Jaya dan Dwirandra. 2014. Pengaruh Pendapatan Asli Daerah Pada Belanja Modal Dengan Pertumbuhan Ekonomi Sebagai Variabel Pemoderasi. EJurnal Akuntansi Universitas Udayana 7.1 :79-92 Mardiasmo. 2002. Akuntansi Sektor Publik. Yogyakarta: Penerbit Andi. 
Mardiasmo. 2004. Akuntansi Sektor Publik. Yogyakarta: Penerbit Andi.

Martini, dkk. 2014. Pengaruh Pendapatan Asli Daerah, Dana Alokasi Umum Dan Dana Alokasi Khusus Terhadap Belanja Modal Pada Kabupaten Buleleng Tahun 2006 2012. e-Journal Bisma Universitas Pendidikan Ganesha. Vol.2.

Prakosa, Kesit Bambang. 2004. Pengaruh Dana Alokasi Umum (DAU) dan Pendapatan Asli Daerah (PAD) terhadap Prediksi Belanja Daerah (Studi Empirik di wilayah Provinsi Jawa Tengah dan DIY). JAAI Vol. 8 No. 2.

Rahman, Herlina. 2005. Pendapatan Asli Daerah.

Ristriardani. 2011. Pengaruh Dana Perimbangan terhadap Pendapatan Perkapita dan Disparitas Pendapatan antar Wilayah di Provinsi Kalimantan Selatan. Tesis Program Magister Perencanaan dan Kebijakan Publik. Universitas Indonesia.

Robert. 2004. Pengaruh Pendapatan Asli Daerah, Dana Alokasi Umum, Dana Alokasi Khusus dan Belanja Modal terhadap Pertumbuhan Ekonomi Kabupaten/ Kota Provinsi Sumatra Utara.

Widjaja, HAW. 2002. Otonomi daerah dan Daerah Otonom. Jakarta: Raja. Grafindo Persada. 